\title{
Democritean Conceptions in Brain Research
}

\author{
Lazaros C Triarhou, ${ }^{1, *}$ \\ ${ }^{1}$ Laboratory of Theoretical and Applied Neuroscience and Graduate Program in Neuroscience and Education, University of Macedonia, Thessalonica, Greece \\ "Corresponding author: Lazaros C Triarhou, Laboratory of Theoretical and Applied Neuroscience and Graduate Program in Neuroscience and Education, University of \\ Macedonia, Thessalonica, Greece, E-mail: triarhou@uom.gr
}

Received 2015 December 28; Accepted 2016 January 04.

\begin{abstract}
Democritus of Abdera (b. circa 460-457 BCE; d. circa 370-351 BCE) has been called the father of modern science. With his teacher Leucippus, they co-founded the atomic theory. Concerning neuroscience, Democritus accepted Alcmaeon's premise of the brain being the seat of the mind, and further formulated a triune concept of the human psyche. He contributed ideas to the physiological mechanisms of the senses and perception, and devoted considerable attention to the theory of knowledge, emphasizing subjectivity and the limitation of the human sensory apparatus.
\end{abstract}

Keywords: Alcmaeon of Croton, Democritus of Abdera, History of Neuroscience, Triune Psyche, Presocratic Philosophers, Atomists

\section{Context}

In the history of human thought, Francis Bacon (1561 -1626) acknowledged the capital importance of the genius of Democritus, ranking him first among the Greek philosophers, a position long occupied by Socrates and Plato $(1,2)$. Born in the Greek polis of Abdera $\left(40^{\circ} 57^{\prime} \mathrm{N}, 24^{\circ} 59^{\prime} \mathrm{E}\right)$ on the northern coast of the Aegean, Democritus (Figure 1, right) is widely known as the laughing philosopher. He was a pupil of Anaxagoras and of Leucippus. With the latter, he co-founded the atomic theory.

Having travelled to Ephesus, Egypt, Ethiopia, Mesopotamia, Persia and India, Democritus was one of the most prolific of all ancient authors, with 73 books to his credit (according to Diogenes Laertius), commonly grouped in tetralogies, and covering most branches of knowledge, including physics, mathematics, geography, navigation, cosmology, ethics, education, philosophy, music theory, anatomy, physiology, medicine, technology, philology, human behavior, and even positive psychology $(3,4)$. His contemporaries gave him the very name of Sophia, or Wisdom (2). His range was as wide as Aristotle's, his style as highly praised as Plato's, his arguments subtle and elegant, and many of his conclusions fundamentally correct $(2,5)$.

Democritus exerted enormous influence on the generations of Greek and Roman philosophers who followed him, even influencing the attitude of the English school of the 17th and 18th century (6). Aristotle is said to have taken up science where Democritus left it (2). Considered the father of modern science (7), Democritus advanced key concepts during the epoch of natural philosophy. Moreover, he came up with key ideas related to the brain and mind sciences.

\section{Prolegomena}

\subsection{Atomism}

Together with Leucippus, Democritus developed and propounded a rounded philosophical system of atomic materialism. He formulated for science its most famous hypothesis, and gave to philosophy a system which, denounced by every other, has survived them all, and reappears in every generation (2). Atomism is in many ways the crown of Presocratic philosophical achievement; being in essence a new conception, widely and skillfully applied by Democritus, it fulfilled the ultimate aim of Ionian material monism and eventually provided the stimulus for the development of modern atomic theory (3).

The historical order of a theoretical conception can be unrelated to the empirical demonstration of a physical hierarchy: Democritus conceived of atoms before they could even be understood in terms of the atomic theory by John Dalton (1766 - 1844) of 1805 or the nuclear theory of the atom as proposed by Ernest Rutherford (1871 - 1937) in 1911 (8). Time, in Democritean atomic theory, is eternal and dateless. Space is made up of mathematical atoms, a second kind of atom, besides physical ones (9).

\subsection{Cosmos}

A student of Babylonian lore, Democritus described the Milky Way as a multitude of stars, and summarized astronomic history as the periodical collision and destruction of an infinite number of cosmoi, or worlds (2). Things 

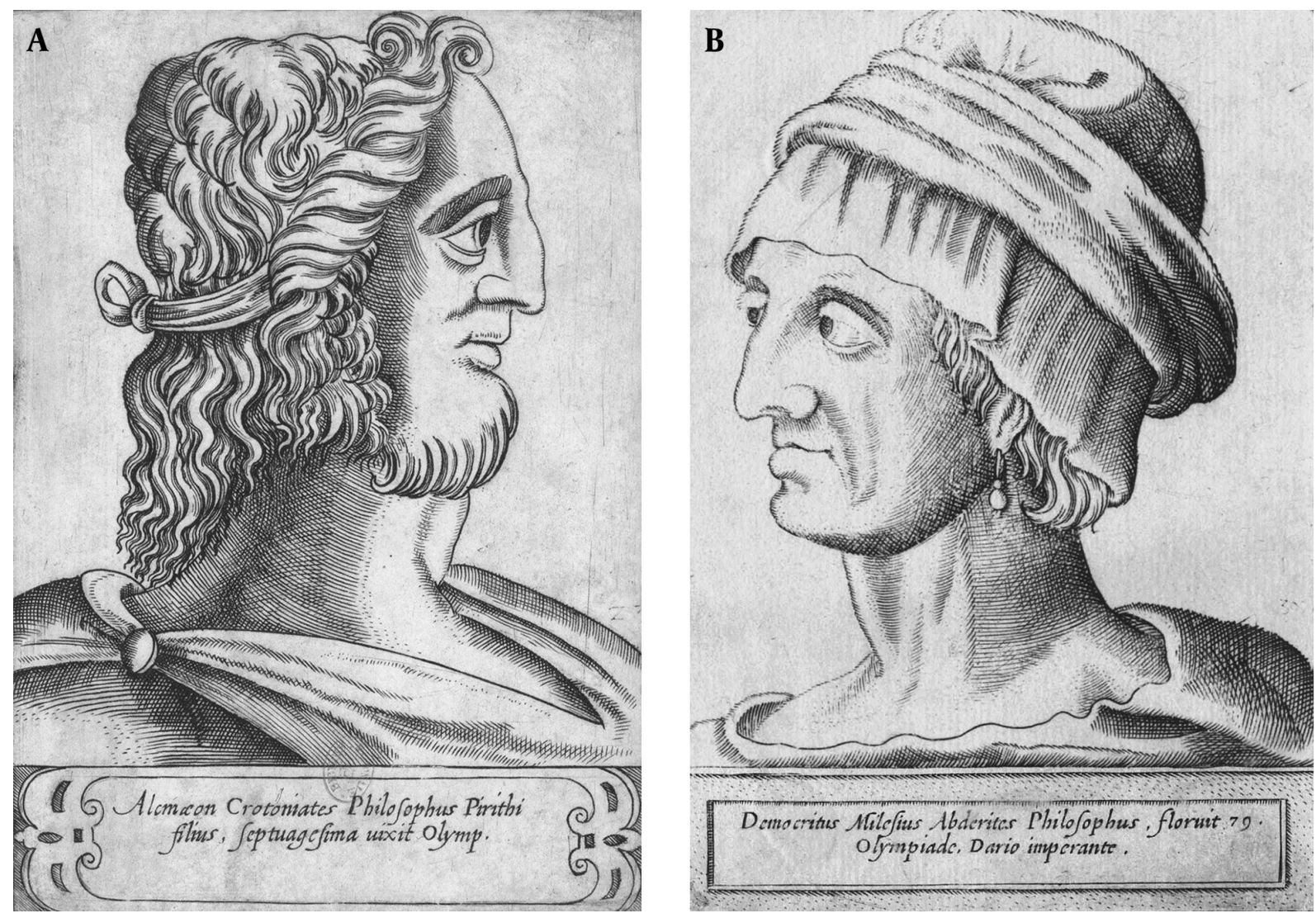

A, Alcmaeon of Croton, son of Peirithus; B, Democritus of Abdera or of Miletus, son of Hegesistratus or Athenocritus or Damasippus. From Illustrium Philosophorum, et Sapientum Effigies ab Eorum Numismatibus Extractae (Girolamo Olgiati, Venice, 1583). Credits: Département Estampes et Photographie, Bibliothèque Nationale de France, Paris (Alcmaeon); Bildarchiv Austria, Österreichische Nationalbibliothek, Vienna (Democritus).

constantly move in the void. Those infinite worlds differ in size; some lack a sun or a moon, some are larger, and some denser than ours. Distances between worlds are unequal. Some worlds grow and flourish, others decay; destruction comes about as worlds collide with each other (3).

Democritus promoted the idea that organic beings and the simplest forms of life on earth arose originally from some kind of moist, primeval ooze $(2,5)$. Other worlds can be devoid of animals and plants and of any liquid (3).

\subsection{Necessity}

In Aristotelian terms, combinations can take place by chance (from chance arose the whirl and movement that brought the universe into its present form); in Democritean terms, non-planned necessity produces the mechanical collisions and unions of atoms, each according to the shape and particular motion of the atoms concerned
(3). Necessity, or anagke, the natural operation of inherent causes, is what guides the atoms; there is no chance: chance is a fiction invented to disguise our ignorance (2).

The phrase by Democritus that everything existing in the universe is the fruit of necessity condenses in a remarkably pithy fashion the essence of the problem that the existence of life poses to philosophers, that is, to what extent is the phenomenon of life a product of blind chance, and to what extent is it an obligatory outcome of deterministic forces. Christian de Duve (10) used the term deterministic in a phenomenological, not doctrinal, sense, applied to the phenomena that led to the appearance of life and meaning that such phenomena were determined entirely by the physicochemical conditions which prevailed at the time they took place and, therefore, they should be reproducible under the same conditions.

Chemistry deals with strictly deterministic, reproducible phenomena that depend on the statistical behav- 
ior of trillions of diverse molecules. Life itself is believed to have arisen through such deterministic chemical processes, its continuity being guaranteed by the strict determinism to which chemistry is subjected. All surmised events in biological evolution are exclusively the products of chemistry, that is, of deterministic, reproducible manifestations, entirely dependent on the prevailing physicochemical conditions (11).

\section{Reflections on Brain and Mind}

\subsection{The Triune Psyche}

Democritus, as well as Hippocrates (in his Corpus), concurred with Alcmaeon's discovery of the brain as the seat of the mind $(6,12)$. Alcmaeon of Croton (Figure 1, left) has been called the real father of Greek medicine; he was the first to recognize the brain, or encephalos, as the central organ of consciousness and thought, or hegemonikon $(2,13)$. Democritus adopted and expanded on Alcmaeon's view of the functions of the brain, as did Anaxagoras of Clazomenae and Diogenes of Apollonia, and developed a version that became especially influential because of its impact on Plato.

The psyche (mind, soul, vital principle) is made up of lighter, spherical, fast-moving atoms. Psychic atoms are dispersed among other atoms throughout the body and are especially numerous in the brain, which is the central organ of consciousness and thought. Life and psyche are movements of a subtle matter, made of spherical atoms, invisible corpuscles that span the entire body as mental principles (archae noerae). The function of sensation and thought (they are one) results from the mobility of the psychic atoms. Democritus and the other natural philosophers made no distinction between the mind (nous) and the soul (psyche); they are absolutely the same thing (1).

Atoms cruder than those of the mind are concentrated in the heart, making it the center of emotion; even cruder atoms are concentrated in the liver, which is the seat of lust and appetite (14). Democritus anticipated Plato's tripartite model of the psyche and named the brain the guard of the mind (phylax dianoies), the heart the queen, nurse of anger (vasilis orges tithenos), and the liver the cause of desire (epithymies aetion). Such a trichotomy developed into Plato's hierarchy of the parts of the soul, set out in detail in Timaeus. Plato further developed his tripartite concept of the psyche in Phaedrus and in the Republic, whereby the organic seat of the rational or intelligent (logistikon), the temperamental or courageous (thymoeides), and the passionate or appetitive (epithymetikon), respectively occupy cerebral, thoracic, and abdominal portions of the cerebrospinal marrow $(15,16)$. In Galen's subse- quent theorizing, those three parts became the three pneumata of humoral physiology (3).

A fragment from Democritus' book On human nature preserves the doctrines of the anatomical and functional localization of intelligence and the sentiments and an anatomical notion of the meninges and the sutures of the cranial bones: The brain guards the citadel of the body, ensuring its safety via coexisting nervous membranes (hymenes neurodeis); over those membranes doubled bones cover the brain, the guardian of the mind (1).

Democritus did not acknowledge the immortality of the psyche, and denied immortal gods and Pythagorean mysticism. After death, the psyche disintegrates into atoms; it perishes, in contrast with the Platonic view of immortality (17) or even with Alcmaeon's view that the soul is immortal as it is similar to the immortal objects by moving forever, because it and all the other objects move continuously (the sun, the moon, the stars, and heaven)(18).

\subsection{Perception and Sensory Physiology}

In humankind's endeavor to understand ourselves, the long history of the development of ideas on perception extends to the time of Democritus. He had postulated that eidola, small images of external objects, were transmitted by atomic movements to the sense organs and from these to sensation. Such images bear an uncanny resemblance to what neurophysiologists call representations (19).

Democritus conceived of perception as a purely physical and mechanistic process; mind and senses were attributes of matter put together in a sufficiently fine and complex manner (5). The perception of quality by the senses results merely from a specific quantitative distribution of atoms; this is the guiding principle in today's neurochemistry.

Empedocles and Democritus expressed observations on sensory perception and adapted them to their general physical and philosophical theory. The mechanisms of sensory perception were further elaborated by Democritus. Perception happens only if the receptive organ has a geometrical shape similar to that of the particles approaching it from the object. Accordingly, sensory specificity is reduced to a structural geometrical specificity of the receiving organ (6).

Democritus specified that the emanation from the object formed a kind of imprint in the air which would be the immediate object of human perception (6). He termed such an imprint, which shapes the space between object and eye, an eidolon, which means a representation, or Gestalt.

In addition, Democritus theorized that all the senses were forms of touch, which was the primary sense $(1,2,15)$ and made all things into passions of the senses (20). The 
number of sensations is greater than those perceived by the senses, and thus remain largely latent (1).

\subsubsection{Vision}

Regarding vision, the first intromission theories, in other words, the idea that vision involves something entering the eye from the object seen, were those of Democritus and Epicurus. These atomists believed that isomorphic images streamed off the objects and entered the eye, where they were sensed (3). Expanding on the ideas of Empedocles of Acragas, Democritus suggested, in his now lost books (On mind, perception, and colors and On the diverse rhythms of atoms and the concepts of forms) that objects emit images (eidola, the actual term of Democritus being deikela), copies of their figure and color, which compress the air between the object of sight and the visual organ, and become imprinted and reflected in the moist eyes. Remnants of that theory can even be found in the writings of Descartes $(6,17)$.

More specifically, Democritus explained vision as the mirroring (emphasis) of objects in the water contained in the organ of vision proper (15). Such a visual image in the pupil results from effluences (aporrhoae) both from the seen object and from the observer; the two meet and form a solid impression (entyposis) in the air, which then enters the pupil. Opposite of the centripetal emanation, from the object of vision to the eye, another emanation is conceived, centrifugal, simultaneous with or preceding the act of vision, from the eye to the object. Such a suggestion was in all likelihood made by Empedocles, and it was embraced by Democritus, Plato, and the Stoic philosophers. It is still used allegorically today in the expression: to throw a glance (6).

Democritus is the earliest philosopher in whose writings we find an attempt at a detailed theory of color vision. According to him, color is a purely subjective thing, in contrast with Plato, who regards colors as objective, and Aristotle, for whom color depends on both the eye and the object and the realization of the potentialities of the two (15). Democritus considered color qualities related to the hypothetical structures of atoms. The theory of color perception arose from experiments with painters' dyes and the optical effect of color mixtures (6). The basic colors were four, differing in atomic structure and corresponding to the four elements (17). Those color primaries were black (charred ivory or bone), white (powdered marble or pulverized seashells), red (vermilion), and yellow (earth ochre). Mixtures of the primaries can produce all known hues. The origin of the Democritean theory of vision may have been the observation of structural differences, such as smooth contours, brittleness and fragility of dyestuffs, in the quest for an objective basis of color perception (6).

\subsubsection{Audition, Taste and Olfaction}

The other senses are explained with emphasis on the different effects of the different sizes and shapes of atoms. We see, hear, smell, taste, and touch by the agency of varying atoms (15). Sound is transferred when the particles of voice or noise mingle with similar particles in the air and thus, presumably, also form eidola; the air is broken up into bodies of like shapes and rolled along together with the fragments of the voice (3).

Individual tastes depend on the physical properties, the form of atoms. All sensible qualities rest on their order, shape and position (15). Democritus appears to be the first scholar to propose a stereochemical theory for the chemical senses: sweet taste is produced by large, round atoms; sour by large, rough, angular atoms; acidic by sharp, angular, curving-thin atoms; pungent by spherical, thin, angular curving atoms; salty by large, not rounded, sometimes jagged atoms; bitter by small, spherical, smooth, of sinuous circumference atoms; and succulent by thin, small spherical atoms (17). Olfaction is also reduced to a tactile mode, like all the other senses.

\subsubsection{Pain}

On pain, Democritus reasoned that shed images, emanated by objects, may stimulate various receptors of the body and affect the mind. He viewed the intrusion of irregularly shaped, hooked atoms into the blood vessels as the cause of pain, experienced in the specific part of the body which is stimulated (17).

\section{Theory of Knowledge}

Everything in the universe is made up of atoms. Accordingly, all knowledge is effected by the mechanical interaction among atoms as well. On the other hand, our knowledge of the world derives from experience through our senses. The senses, however, are not in direct contact with the nature of things, thus leaving room for omission or error and a gap between what we can perceive and what exists in reality. Democritus was aware of the fundamental difference between subjective sense impressions and their objective physical causes. His cognizance of the constraints of human knowledge becomes apparent in his aphorism, I would rather discover a single cause than accede to the throne of the Persian kingdom $(5,6)$.

In Democritus one finds the earliest origin of the modern laws and theories on the nature of sensations and ideas. In that respect, Democritus is the great ancestor of George Berkeley (1685 - 1753), as in the latter's idealism, or immaterialism, there is no other scientific foundation than the celebrated propositions in which Democritus demonstrated an absolutely subjective character (1). 
Bodily sensations are pure appearances. None of the senses appears according to truth but only according to opinion. In reality, nothing exists but atoms and the void.

Concerning epistemology, Pierre Cabanis (1757 - 1808), like Democritus and most materialists, thinks exactly the same way as the great idealists of the Berkeley tradition. Cabanis said: Since our ideas are only the results of our comparative sensations, there can only be relative truths in the general manner of the human senses; the pretention of knowing the essence of things properly is an absurdity that even the minutest attention perceives as evident (1).

There are two forms of knowledge, one through sensory perception (aisthesis), the other through reflection (dianoia). The first is dark, lacking inerrancy in the discrimination of truth; the second is genuine, associated with fidelity in the judgment of truth (3). Democritus made the distinction, like all previous physiologists, between sense and reflection, albeit both had the same origin. If contemporary science established a truth, it is that, inside and outside of us, we only perceive phenomena through our senses, which, far from being faithful representations of things, are only obscure symbols. According to Soury (1), such a wise idealism does not essentially differ between the materialism of Democritus and the immaterialism of Berkeley.

\section{Conclusions}

Of the ancients, Democritus came closest to many of our modern concerns. For him, sensation and thought had a material basis and depended on concrete, fine, polished and round atoms; all sensations and images resulted from a change in the position of these particles in space (14). The Abderite bridged the gap between mental and molecular events through a mechanical connection: the atoms, their different shapes, and their spatial arrangement (6).

Democritus assigned the intellectual and affective faculties that he distinguished to precise locations in the body. His psychic atoms constituted the material basis for exchanges between the brain, the other organs of the body, and the outside world, thus anticipating the notion of nervous activity, which, in the final analysis, can be explained by atomic properties or, more precisely, in today's neurochemical terms, by the ions which cross neuronal membrane channels and the neurotransmitters that bind to their receptors. Therefore, the nervous system of living organisms is made up of the same stuff as the inanimate world, organized into molecular building blocks, which mediate cell communication, cellular metabolism, and cell replication (14).

Since the time of Pierre Gassendi (1592 - 1655), and through the era of René Descartes (1596 - 1650), Isaac New- ton (1642 - 1727), and Robert Boyle (1627 - 1691), the capital theory of Democritus, the doctrine of the atoms and the systematic explication of all phenomena of the universe through the movement of these particles has become the very foundation of the sciences. Physics and chemistry are still based on atomism, and no new hypothesis on the constitution of matter has replaced the ancient idea. The atomic theory has retained its validity: it was not a religious dogma but rather a temporary and legitimate hypothesis, hence scientific (1).

The conviction, on the other hand, of the value of learning, with all its limits, is evident in the aphorism: culture is better than riches; no power and no treasure can outweigh the extension of knowledge (2).

\section{References}

1. Soury J. Le systeme nerveux central; structure et fonctions: histoire critique des theories et des doctrines. Paris: Carre et Naud; 1899.

2. Durant W. The life of Greece. New York: Simon and Schuster; 1966.

3. Kirk GS, Raven JE, Schofield M. The presocratic philosophers: a critical history with a selection of texts. Cambridge: Cambridge University Press; 1983.

4. Magiorkinis E, Beloukas A, Diamantis A. The philosophic and biological views of the atomic philosophers, Leucippus and Democritus. Hell J Nucl Med. 2010;13(2):111-7. [PubMed: 20808983].

5. Sagan S. Cosmos. New York: Random House; 1980.

6. Siegel RE. Theories of vision and color perception of Empedocles and Democritus; some similarities to the modern approach. Bull Hist Med. 1959;33(2):145-59. [PubMed: 13651827]

7. Bromberg SJ. Antiquity, 500 BCE-AD 476. In: Gossin P, et al, editors. Encyclopedia of Literature and Science. Westport(CT): Greenwood Press; 2002. pp. 234-7.

8. Jacobson M. Foundations of neuroscience. New York: Plenum Press; 1993.

9. Lurie SY. Democritus: The texts, translation, research. Leningrad, Nauka Publ; 1970.

10. de Duve C. Blueprint for a cell: the nature and origin of life. Burlington (NC): Neil Patterson/Carolina Biological Supply Company. 1991.

11. de Duve C. Life evolving: molecules, mind, and meaning. New York: Oxford University Press; 2002.

12. Doty RW. Alkmaion's discovery that brain creates mind: a revolution in human knowledge comparable to that of Copernicus and of Darwin. Neuroscience. 2007;147(3):561-8. doi: 10.1016/j.neuroscience.2007.02.046. [PubMed: 17428612].

13. Outes DL, Orlando JC. Alcmeon de Crotona (El cerebro y las funciones psiquicas). Neuropsiquiatria y Salud Mental. 1982;13:53-64.

14. Changeux J. Neuronal man: The biology of mind. New York: Pantheon Books; 1985.

15. Beare JI. Greek theories of elementary cognition from Alcmaeon to Aristotle. Oxford: Clarendon Press; 1906.

16. Triarhou LC. Tripartite concepts of mind and brain, with special emphasis on the neuroevolutionary postulates of Christfried Jakob and Paul MacLean. In: Weingarten SP, Penat HO, editors. Cognitive psychology research developments. Hauppauge, NY: Nova Science Publishers; 2009. pp. 183-208.

17. Finger S. Origins of neuroscience: a history of explorations into brain function. New York: Oxford University Press; 1994.

18. Codellas PS. Alcmaeon of Croton: his life, work, and fragments. Proc $R$ Soc Med. 1932;25(7):1041-6. [PubMed: 19988748]. 
19. Mountcastle VB. Perceptual neuroscience: the cerebral cortex. Cambridge: Harvard University Press; 1998. pp. 1041-6.
20. Theophrastus . Theophrastus on the senses. Athens, GR: Cactus; 1998. pp. 197-283. 